\title{
Pulzusváltozások vizsgálata különbözó instabil felïleteken végzett gyakorlatok során Investigation of pulse changes during exercises on unstable surfaces
}

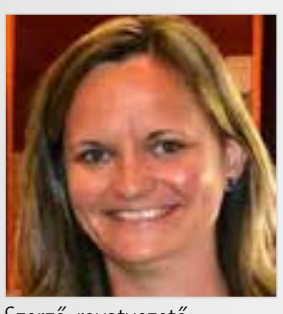

Szerző, rovatvezető: DR. NAGYVÁRADI KATALIN Egyetemi adjunktus ELTE Sporttudományi Intézet nagyvaradi.katalin@ppk.elte.hu Főbb kutatási területei: rekreáció, egészségfejlesztés, vízi sportok

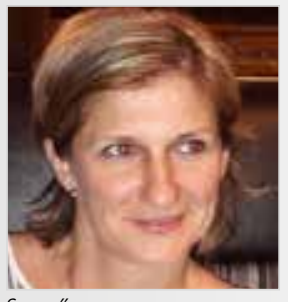

Szerző: BIRÓNÉ DR. ILICS KATALIN Egyetemi adjunktus ELTE Sporttudományi Intézet birone.lics.katalin@ppk.elte.hut Főbb kutatási területei: rekreáció, kiválasztás, tehetséggondozás, versenysport

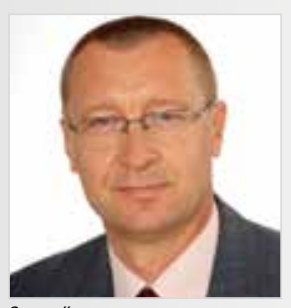

Szerzō: DR. POLGÁR TIBOR Egyetemi docens ElTE Sporttudományi Intézet polgar.tibor@ppk.elte.hu Főbb kutatási területei: rekreáció, síelés, kajakozás, turizmus

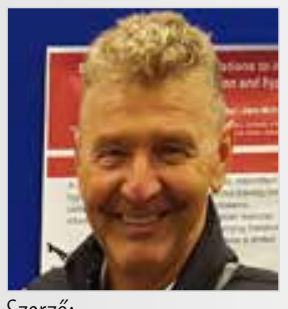

Szerző: PROF. DR. IHÁSZ FERENC Egyetemi tanár ELTE Sporttudományi Intézet ihasz.ferenc@ppk.elte.hu Föbb kutatási területei: terhelésélettan, prevenció, egészségfejlesztés

ÖSSZEFOGLALÁS: A rekreációs piacon folyamatosan jelennek meg azok az edzéseszközök, melyek segíthetik az inaktivitás ellensúlyozását, az aktív szabadidő-eltöltést, a mozgás általi prevenciót. Az edzéseken használt eszközök között gyakran találunk olyanokat, melyek instabil felületet képezve segítik az egyént az aktivitás megőrzésében, edzéscéljának elérésében. Instabil felületek közé sorolható, a teljesség igénye nélkül a bosu, a dyner párna és a vízen használatos stand up paddle. Jelen kutatás célja: két különböző instabil felületen végzett statikus és dinamikus gyakorlatok során bekövetkezett pulzusszámválaszok, összesített edzéshatás, felhasznált kalória és a pihenési idők összehasonlítása. Kulcsszavak: aquapaddle, bosu, statikus, dinamikus gyakorlatok, pulzusváltozás

ABSTRACT: In an attempt to mimic everyday activities that are performed in the different dimensional environments, exercise programs have been designed to integrate training of the trunk muscles with the training of the extremities. Many believe that the most effective way to recruit the core stabilizing muscles is to execute traditional exercise movements on unstable surfaces. However, physical activity is rarely performed with a stable load on an unstable surface; usually, the surface is stable, and the external resistance is not. Improvements in postural stability from balance training without resistance can improve force output which can then lead to a training progression involving an amalgamation of balance and IRT leading to higher load traditional resistance training. Purpose of the present study: Comparison of heart rate responses, total training effect, calories used and rest periods during static and dynamic exercises on two unstable surfaces. Keywords: stand up paddle, unstable surface training, training load

\section{Bevezetés}

Az emberi teljesítőképesség megóvásának, fejlesztésének fontos feltétele a mindennapi életvitel keretében megvalósuló szellemi és fizikai rekreáció. Ennek lényege, hogy a megélhetés aktuális forrását jelentő, többnyire egyirányú, gyakran monoton és megerőltető igénybevételt ellensúlyozza, és a lehetőségekhez képest ápolja, funkcióképes állapotban tartsa a már megszerzett készségeket - képességeket, őrizze az egyén adaptációs készségét, ellenálló képességét (Fritz, 2019a).

A mozgásos rekreáció olyan gyakorlatok végrehajtásából álló tevékenység, melynek célja az egyén egészségének megőrzése és fejlesztése, teljesítő- és munkavégző képességének helyreállítása és szükség szerint annak növelése (Fritz, 2019b).

A rekreációs piacon folyamatosan jelennek meg azok az edzéseszközök, melyek segíthetik a mozgásos rekreáció céljának elérését, az inaktivitás ellensúlyozását, az aktív szabadidő eltöltést, a mozgás általi prevenciót. Az edzéseken használt eszközök között gyakran találunk olyanokat, melyek instabil felületet képezve segítik az egyént az aktivitás megőrzésében, az edzés céljának elérésében.

Instabil felületeknek nevezzük azokat a felszíneket, amelyeken a test alátámasztása bizonytalan, ingatag, használatuk során sorozatos egyensúlyvesztés következik be. Emiatt az egyensúly fenntartásában az összes izomnak folyamatosan részt kell vennie, korrigálnia kell, így azok automatikusan ellentartanak. Az instabil felületen a támasz szinte valamennyi testrész alatt lehetséges, például: talp, térd, has, alkar, tenyér. A gyakorlatok kiválasztásánál statikus és dinamikus feladatokat is végeztethetünk.

A dinamikus gyakorlat izomhosszváltozással és ízületi mozgással járó ritmikus kontrakció

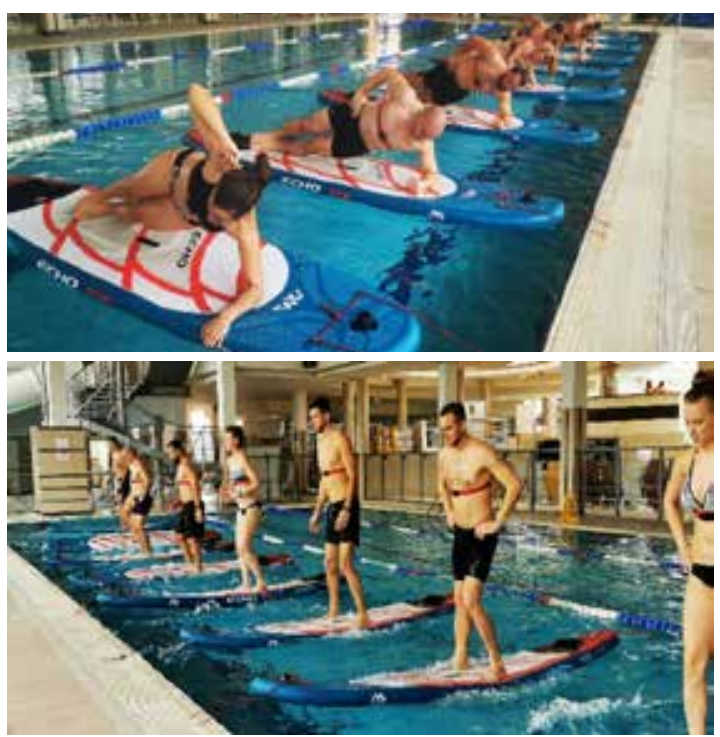

1-2. ábra: Statikus és dinamikus gyakorlatok aquapaddle-n

Static and dynamic exercises on the aquapaddle 
(Pavlik, 2011; Maron BJ, et al, 2005), ami relatív kis erőfejlesztéssel jár, továbbá fejleszti az ügyességet, állóképességet, és jótékony hatású a keringési rendszerre. Statikus mozgás esetén relatív nagy erő keletkezik az izomhossz változása, illetve az ízületi elemek helyváltozása nélkül (Pavlik, 2011; Maron BJ, et al, 2005). A terhelés során ezzel szemben az oxigénfogyasztás alig emelkedik, csakúgy, mint a szívfrekvencia és a pulzusvolumen. Ebből látható, hogy míg a dinamikus terhelés a szívnek volumenterhelést jelent, addig a statikus izommunka nyomásterhelést ( $M a-$ ron BJ, et al, 2005), amit a szív sokkal rosszabbul tolerál.

Jelen kutatás célja: két különböző instabil felületen végzett statikus és dinamikus gyakorlatok során bekövetkezett pulzusszámválaszok, az összesített edzéshatás, a felhasznált kalória és a pihenési idők összehasonlítása.
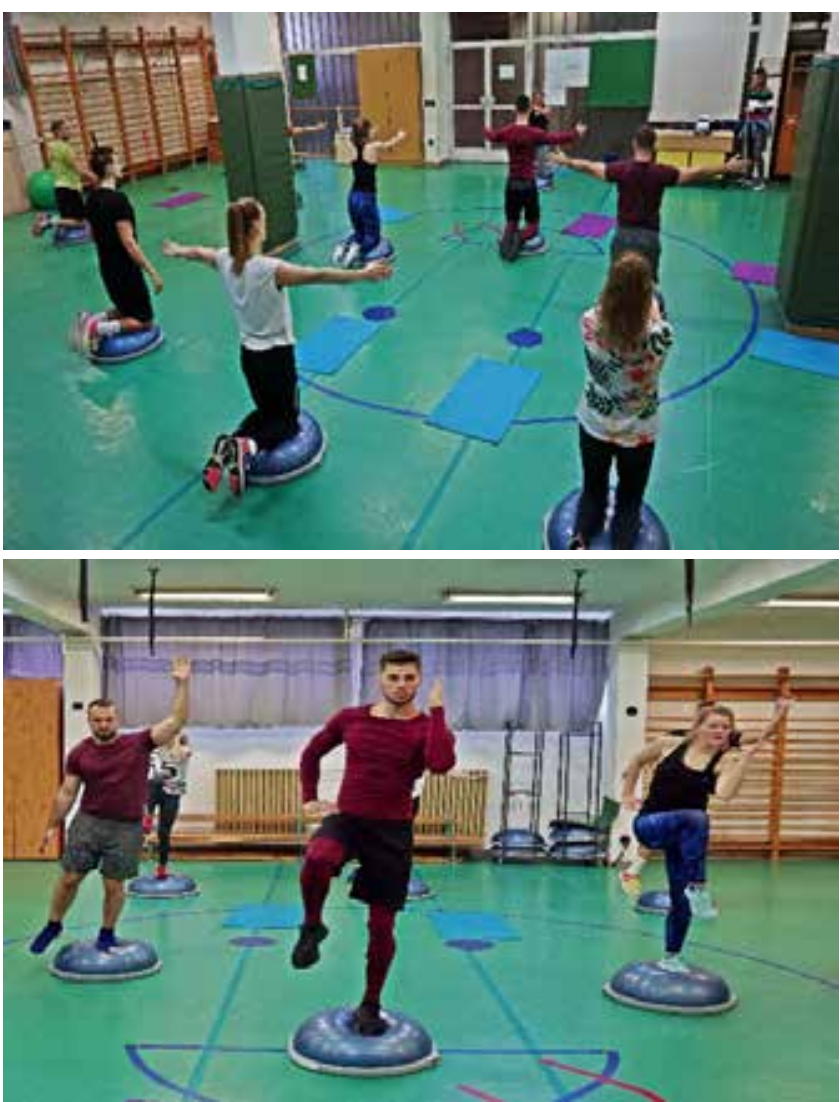

3-4. ábra: Statikus és dinamikus gyakorlatok bosun Static and dynamic exercise on the bosu

\section{Anyag és módszerek}

Vizsgálatainkat 2019 novemberében a Sárvári Gyógyfürdő Kft. wellnessrészlegének 25 méteres úszómedencéjében, illetve az ELTE PPK Sporttudományi Intézet-Szombathely gimnasztikatermében valósítottuk meg. A résztvevők $(N=9)$ az ELTE PPK Sporttudományi Intézet sportszakos hallgatói voltak. Átlagéletkoruk 23,3+/- 1,19 év (nő: 22,5 év, férfi: 23,8 év), testtömegátlaguk 73,2+6-35,81 kilogramm (nö: 61,o kg, férfi: $83,0 \mathrm{~kg}$ ), testmagasságuk átlaga 176,8+/- 27,48 cm (nö: 169,2 cm, férfi: $183 \mathrm{~cm}$ ). A vizsgálathoz kétféle instabil felületet választottunk ki, az egyik a szárazföldön használt, ma már sokak által ismert bosu, a másik az új trendnek számító, vízfelületre helyezhető aquapaddle. Az úszómedencében az aquapaddle-ket a medence széléhez illetve a sávelválasztó kötélhez rögzítettük. A gimnasztikateremben a talajra helyezett bosukon végeztük a gyakorlatokat. Mindkét felületen ugyanazt a statikus és dinamikus gyakorlatsort hajtották végre a résztvevők. Az első foglalkozáson statikus - izomhosszváltozás nélküli, - a másodikon dinamikus - izomhosszváltozással járó - gyakorlatokat végeztettünk. A pulzusszámváltozásokat [(intenzitás zónában töltött idő (sec), gyorsítások-lassítások ( $d b)$, Training Load Score (TLS), felhasznált energia (Kcal)] Polar Pro Team $®$ (Polar Electro Finnland 202O) rendszer segítségével rögzítettük.

$\mathrm{Az}$ adatokat Statistica for Windows 13.0 statisztikai programcsomaggal elemeztük. A statikus és a dinamikus gyakorlatok során rögzített pulzusszám átlagait, illetve ezen gyakorlatok ugyanazon jellemzőit szárazföldön és vízen Repeated ANOVA Post Hoc. Tukey (HSD) módszerével hasonlítottuk össze.

A kutatás a 2019/344-es kutatásetikai engedély alapján került megvalósításra. A publikáció az „EFOP-3.6.1-162016-00018 - A felsőoktatási rendszer K+F+I szerepvállalásának növelése intelligens szakosodás által Sopronban és Szombathelyen" című projekt támogatásával valósult meg.

\section{Eredmények}

Az 1. táblázat a szárazföldi és a vízi, statikus és dinamikus gyakorlatok során rögzített átlag- (HR avg) és maximális (HR max) pulzusszámot, az egyes pulzuszónákban (1-5) eltöltött időt, ezek összesített értékét Training Load Score (TLS), a felhasznált kalóriamennyiséget (Kcal) és a javasolt regenerációs időt $(h)$ átlag, minimum, maximum értékeit és azok szórásait tartalmazza.

\section{1. táblázat: A kiválasztott adatok leíró statisztikája The descriptive statistics of selected data}

Magyarázat: $\operatorname{HR}(\max )=\mathrm{a}$ terhelés csúcsán rögzített pulzusszám (ütés $\times$ perc $^{-1}$ ), HRavg=a terhelés során mért pulzusszám átlag (ütés $\times$ perc $^{-1}$ ), Time in HR zone 1, 2,3,4,5=a terhelési zónákban töltött idő (sec.), Training Load Score=a terhelési zónákban töltött idő összesített mutatója (TLS), Calories=a terhelés során felhasznált kalória (Kcal), Recovery time $=$ a terhelés utáni megnyugvás idő (h), stat_sz=statikus szárazföldi gyakorlatok, din_sz.= dinamikus szárazföldi gyakorlatok, stat. v.= statikus vízi gyakorlatok, din._v= dinamikus vízi gyakorlatok.

\begin{tabular}{|c|c|c|c|c|}
\hline & $\begin{array}{l}\text { stat. sz. (1) } \\
\text { átlag }\end{array}$ & $\begin{array}{l}\text { din. sz. (2) } \\
\text { átlag }\end{array}$ & $\begin{array}{l}\text { stat. v. (3) } \\
\text { átlag }\end{array}$ & $\begin{array}{l}\text { din. v. (4) } \\
\text { átlag }\end{array}$ \\
\hline HR max [bpm] & $159,11 \pm 18,57$ & $175,78 \pm 13,06$ & $160,67 \pm 17,73$ & $157,33 \pm 17,97$ \\
\hline HR avg [bpm] & $137,33 \pm 19,14$ & $152,78 \pm 15,30$ & $126,56 \pm 16,08$ & $130,44 \pm 15,72$ \\
\hline $\begin{array}{c}\text { Time in HR zone } 1 \\
(50-59 \%)\end{array}$ & $230,67 \pm 73,26$ & $55,44 \pm 98,78$ & $325,56 \pm 141,16$ & $269,44 \pm 118,65$ \\
\hline $\begin{array}{c}\text { Time in HR zone } 2 \\
(60-69 \%)\end{array}$ & $370,89 \pm 194,26$ & $285,22 \pm 149,69$ & $362,56 \pm 159,91$ & $537,78 \pm 198,30$ \\
\hline $\begin{array}{c}\text { Time in HR zone } 3 \\
(70-79 \%)\end{array}$ & $333,11 \pm 171,84$ & $358,78 \pm 309,00$ & $298,00 \pm 114,86$ & $263,00 \pm 232,66$ \\
\hline $\begin{array}{c}\text { Time in HR zone } 4 \\
(80-89 \%)\end{array}$ & $0,00 \pm 0,00$ & $445,44 \pm 207,76$ & $62,56 \pm 85,18$ & $115,78 \pm 83,27$ \\
\hline $\begin{array}{c}\text { Time in HR zone } 5 \\
(90-100 \%)\end{array}$ & $12,22 \pm 36,67$ & $112,00 \pm 264,82$ & $4,78 \pm 11,09$ & $15,56 \pm 37,62$ \\
\hline Training load score & $31,44 \pm 16,73$ & $45,33 \pm 15,66$ & $22,33 \pm 13,62$ & $27,22 \pm 13,30$ \\
\hline Calories [kcal] & $198,44 \pm 75,63$ & $241,78 \pm 82,92$ & $168,33 \pm 62,03$ & $188,44 \pm 58,23$ \\
\hline Recovery time [h] & $13,19 \pm 10,15$ & $13,19 \pm 9,15$ & $6,48 \pm 4,17$ & $6,48 \pm 3,17$ \\
\hline
\end{tabular}


A legnagyobb értékeket a dinamikus szárazföldi gyakorlatok során mértük (175.78 \pm 13.06$)$, a legkisebbet pedig a vízben végzett dinamikus gyakorlatok során. Az átlagpulzusszámok 130.44 $\pm 15 \cdot 72-152.78 \pm 15.30$ között változtak. A regenerálódási idő $(h)$ a szárazföldi gyakorlatok során (mind a statikus, mind a dinamikus) kétszer annyi, mint a vízi gyakorlatok esetében. A statikus, valamint a dinamikus vízi gyakorlatok esetében a második (Time in HR zone 2 6o-69\%-a) pulzuszónában tartózkodtak a legtöbbet a vizsgált személyek. A dinamikus, szárazföldön végrehajtott gyakorlatok esetében a legtöbb tartózkodás a negyedik (Time in HR zone 4 80-89\%-a) zónában

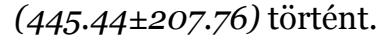

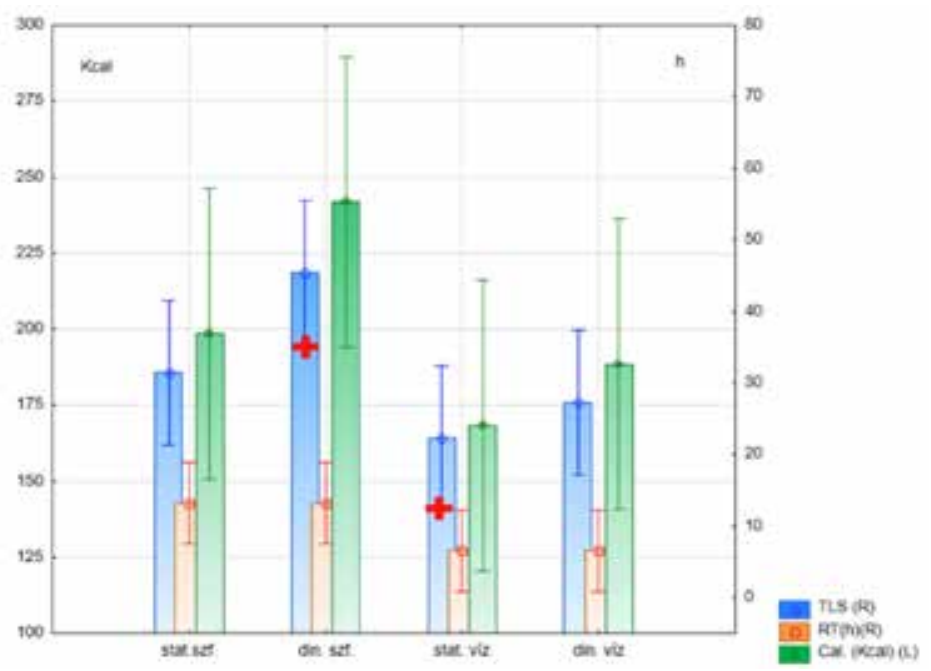

5. ábra: Különböző felületen végzett statikus és dinamikus gyakorlatok összehasonlítása Comparison of static and dynamic exercises on different surfaces.

Magyarázat: TLS=Trainig Load Score, RT=Pulzusmegnyugvás (ütés $\times$ perc-1), Cal=Kalóriafelhasználás (Kcal), +=szignifikáns különbség $(p<0.05)$

A terhelés kumulált mennyiségét mutató Training Load Score (TLS) átlagértékei a gyakorlattípusok közül a szárazföldön elvégzett dinamikus gyakorlatok során voltak szignifikánsan magasabbak, mint a statikus párjaik $[($ TLSstat $-T L S d i n)=(31.44 \pm 16.73-45 \cdot 33 \pm 5.66)] ; \quad \mathrm{p}<0.05$. A szárazföldi, illetve a vizes helyszínek tekintetében a szárazföldön végzett edzéseken (statikus és dinamikus egyaránt) mértünk nagyobb értékeket. A pulzusmegnyugvás átlagai ( $R T)$ szintén a szárazföldi gyakorlatok végrehajtása során voltak nagyobbak, azonban a statikus és dinamikus terhelés tekintetében nem találtunk különbséget. A kalóriafelhasználás (Kcal) nagyobb a dinamikus gyakorlatok elvégzése után, illetve nagyobb a szárazföldön, mint a vízen. Valódi különbséget azonban egyik esetben sem találtunk, aminek az oka az átlagok körüli nagy szórások.

\section{Megbeszélés és következtetések}

A kutatás során alkalmazott mozgásformák előnyei, hogy könnyen hozzáférhetőek és megtanulhatóak, valamint kímélik az ízületeket. Ezen tevékenységek nyilvánvaló pszichológiai előnye - elsősorban a mozgásformák elvégzésének élvezete - kiváló alternatívát jelent az aerob, anaerob intenzitászónák kezelésére a nagy intenzitású feladatok során fellépő kellemetlen élmények megélésére. A legtöbb időt az 1-3 intenzitás zónában töltötték a résztvevők, amiből a harmadik zóna már érintheti az anaerob töréspontot. Sőt az ötödik zónában is végeztek tevékenysé- get, ami kifejezetten anaerob energiafelhasználás igényü (Kessler HS,. at. al, 2014, AIHW; 2014).

Az edzésterhelést minősítő szám (TLS) a szárazföldi dinamikus gyakorlatokban volt a legnagyobb $(45,33 \pm 15,66)$, ettől 14 ponttal a szárazföldi statikus gyakorlatok következnek, $(31,44 \pm 16,73)$. A vízen végzett dinamikus és statikus gyakorlatok terhelése $(27,22 \pm 13,30 v s .22,33 \pm 13,62)$ kevésbé különbözik. Viszont a szárazföldi és a vízi terhelés numerikusan különböznek egymástól. A szignifikáns különbség elmaradása az alacsony elemszámnak és az átlagok körüli jelentős szórásnak tulajdonítható.

Az instabil felületen történő gyakorlatoknak a szakirodalom alapján ugyan nincs teljesítményfokozó hatása, azonban a pulzusértékekből látható, hogy a folyamatos stabilizáció miatt fokozott izommunkát követelnek az izmoktól. Az eddig ismert instabil felületek mellett az aquapaddle alternatívát jelenthet a core izmok és a szív - és érrendszer fejlesztésére, ezt támasztják alá Kibele és Behm (2009), Behm és mtsai, (2010) kutatásai is.

\section{Irodalomjegyzék}

Anderson KG and Behm DG. (2004): Maintenance of EMG activity and loss of force output with instability. J Strength Cond Res 18: 637-640.

Anderson KG and Behm DG. (2005): Trunk muscle activity increases with unstable squat movements. Can J Appl Physiol 30: 33-45.

Australian Institue of Health and Welfare-Australis's health (2014). In: Australia's healts series. Canberra: AlHW; 2014.

Behm DG, Anderson KG, and Curnew RS. (2002): Muscle force and activation under stable and unstable conditions. J Strength Cond Res 16: 416-422.

Ben Schram, et al (2016): The physiological, musculoskeletal and psychological effects of stand up paddle boarding. BMC Sports Science, Medicine and Rehabilitation volume 8 , Article number: 32 https://bmcsportsscimedrehabil.biomedcentral.com/articles/10.1186/s13102-0160057-6 (letöltve, 2019.11.28.)

Biróné Ilics K., Nagyváradi K., Polgár T. (2019): Fitneszórák pulzuskontrollal. I. Leisure Konferencia, Miskolc.

Cosio-Lima LM, Reynolds KL, Winter C, Paolone V, and Jones MT. (2003): Effects of physioball and conventional floor exercises on early phase adaptations in back and abdominal core stability and balance in women. J Strength Cond Res 17: 721-725.

Csajági E (2016): A szív edzésadaptációja a sportágak dinamikus-statikus beosztásának függvényében, valamint az edzésciklusok hatása a kardiális adaptációra. Doktori értekezés.

Fritz P. (2019a): A rekreáció fogalma, rendszertani felosztása. In: Fritz P. (szerk.) Alapfogalmak és jelentéseik a rekreáció területén: Rekreáció mindenkinek III. Miskolci Egyetemi Kiadó, pp. 29. ISBN 978615-5626-38-8

Fritz P. (2019b): A rekreáció fogalma, rendszertani felosztása. In: Fritz P. (szerk.) Alapfogalmak és jelentéseik a rekreáció területén: Rekreáció mindenkinek III., Miskolci Egyetemi Kiadó, pp. 32. ISBN 978615-5626-38-8

Kessler HS, Sisson SB, Short KR. The potential for high-intensity interval training to reduce cardiometabolic disease risk. Sports Med. 2012;42(6):489-509.Testnevelési Egyetem, Budapest.

Kibele, A., Behm, D.G. (2009): Seven weeks of instability and traditional resis- tance training effects on strength, balance and functional performance. Journal of Strength and Conditioning Research, 23:

Jessica B. Andres (2016): Hearth rate response and energy cost of stand up paddleboarding. College of Science and Health Clinical Exercise Physiology.

Koshida S, Urabe Y, Miyashita K, Iwai K, and Kagimori A. (2008): Muscular outputs during dynamic bench press under stable versus unstable conditions. J Strength Cond Res 22: 1584-1588.

Maron BJ, Zipes DP. (2005) 36th Bethesda Conference: Eligibility Recommendations for Competitive Athletes With Cardiovascular Abnormalities. J Am Coll Cardiol, 45: 735-1097.

Marshall PWM and Murphy BA (2006): Increased deltoid and abdominal muscle activity during Swiss ball bench press. J Strength Cond Res 20: 745-750.

Marshall, Paul W M; Desai, Imtiaz (2010): Electromyographic Analysis of Upper Body, Lower Body, and Abdominal Muscles During Advanced Swiss Ball Exercises Journal of Strength and Conditioning Research: June 2010 - Volume 24 - Issue 6 - p 1537-1545 doi: 10.1519/JSC. 0b013e3181dc4440

McBride JM, Cormie P, and Deane R. (2006): Isometric squat force output and muscle activity in stable and unstable conditions. J Strength Cond Res 20: 915-918.

Mitchell JH, Haskell WL, Snell P, Van Camp SP. (2005) Task Force 8: Classification of sports. J Am Coll Cardiol, 45: 1364-1367.

Nagyváradi K. és mtsai (2018): Egy deszka, egy lapát. Recreation magazin VIII/4. ISSN: 2064-4981.

Nagyváradi K., Biróné Ilics K., Polgár T (2019): Aquapaddle, mint instabil felület szerepe a core izmok fejlesztésében. I. Leisure Konferencia, Miskolc.

Palakovich, H., Cuddy, J., and Ruby, B. (2013). Metabolic and energy requirements for stand up paddleboarding. International Journal of Exercise Science: Conference Proceedings. 8(1)

Pavlik G (2011): Élettan-sportélettan. Medicina Könyvkiadó Zrt., Budapest.

Sternlicht E, Rugg S, Fujii LL, Tomomitsu KF, and Seki MM. (2007): Electromyographic comparison of a stability ball crunch with a traditional crunch. J Strength Cond Res 21: 506-509. 9. 2443-2450. 